\title{
DETERMINATION OF CRITICAL IRRADIANCE AND OVERALL EFFICIENCY TO LIFT WATER BY SOLAR ENERGY SYSTEM
}

\author{
A. M. Okasha ${ }^{1}$
}

\section{ABSTRACT}

Egypt is now facing the problem of invasion of the desert and the scarcity of water for agriculture and lack of energy in remote locations. This research has been concentrated on determination of critical irradiance and overall efficiency of $P V$ panel and centrifugal pump system was used to lift water from wells. Therefore, the experimenters were carried out in summer and winter 2014/2015 at Faculty of Agriculture, Kaferelsheikh University, Egypt. The experimental studies were confined to determine: the effect of daytime, solar radiation intensity and 2, 3 and $4 m$ water heads. The results indicated that, the critical irradiance at heads of 2m, $3 m$ and $4 m$ were 257.14, 328.57 and $628.57 \mathrm{~W} / \mathrm{m}^{2}$, respectively in summer. It was 242.86, 285.71 and $571.43 \mathrm{~W} / \mathrm{m}^{2}$ at water heads of 2,3 and $4 \mathrm{~m}$, respectively in winter. The maximum values of pump discharge were 48.82, 47.92, 44.911/min at heads of 2, 3, 4m, respectively in daytime of $1 P M$ and summer. The maximum values of pump discharge were 48.83, 47.54, 44.49l/min at 2, 3 , $4 \mathrm{~m}$, respectively in daytime of $12 P M$ and winter. The maximum time intervals were about of 10, 9.5 and $9 \mathrm{~h}$ in summer and 8.0, 7.5 and 7.0h in winter at 2, 3 and 4m water head, respectively. When solar radiation increased by $42.86 \%$ and the output electric power by $36.67 \%$, the pump discharge and hydraulic power increased by 27.39 and $34.22 \%$ in summer 34.47 and $13.33 \%$, winter, respectively at head of $4 \mathrm{~m}$. Winter in comparison to summer, the overall efficiency of system increased by $35.02,37.78$ and $40.57 \%$ at water heads of 2, 3 and 4m, respectively.

\section{INTRODUCTION}

The awareness of the world to the energy crisis has turned
scientists and engineers towards harnessing of an alternate energy
sources. Solar energy being such a potential source, attempts is being made to harness it for domestic and agricultural applications.

\footnotetext{
${ }^{1}$ Asst. Prof. Agric. Eng. Dept., Faculty of Agric., Kafrelsheikh University, Egypt.
} 
Hamidat et al. (2000) showed that the photovoltaic water pumping systems (PVPS) offer the appropriate solution to supply water for drinking and irrigation in remote regions. Currently, the use of photovoltaic pumps for small-scale irrigation presents a promising option for using solar energy productively and for generating income. Vilela and Fraidenraich (2001) discussed the behavior of water supply systems and found that there was strongly dependent upon the critical radiation level, $\left(\mathrm{I}_{\mathrm{C}}\right)$. This parameter determines at what time of the day the pumping system starts working and at what time it stops. According to the proposed water load profile, it is expected that some water demand will be present in the morning and in the evening, when the system has not started pumping or is no longer working. Awady et al. (2002) showed that photovoltaic powered water pumping systems require adequate sunshine and a source of water. The use of photovoltaic power for water pumping was appropriate, as there was often a natural relationship between the availability of solar power and the water requirement. The water requirement increases during hot weather periods when the solar radiation intensity is high and the output of the solar array is at its maximum. Vilela et al. (2003) found that the critical irradiance level increased, by decreasing water pumping capacity. A system with high $\left(\mathrm{I}_{\mathrm{C}}\right)$ presents a large benefit ratio for the pumped water volume, it will indeed, pump less water than systems with lower critical levels. Pande et al. (2003) showed that the discharge increased by decreasing operating pressure head. Hamidat et al. (2003) revealed that the photovoltaic water pumping system could easily cover the daily water needs rates for small-scale irrigation with an area smaller than two ha. Also, he said there was possible to use a photovoltaic water pumping system for small-scale irrigation of crops in Algerian Sahara regions with low operating pressure head. Badescu (2003) said that the PV array supplies electricity to both battery and motor. However, during periods with decreasing solar irradiance the battery acts as a buffer, supplying electricity to the motor. Kasem (2004) mentioned that Egypt is one of solar belt's countries and its economy depends on irrigated agriculture. There is an importunate need for pumps work with solar energy to pump ground water. El-sayed et al. (2005) mentioned that there are two solar 
pumping techniques: The first is the thermal methods depend upon vapor production. The released vapor with high pressure from the solar concentrating collectors was used to operate a turbine, which operates the water pump. Disadvantage of this method is the low efficiency and high cost. The second technique is using solar cells to generate electric power during the converting of the sunlight into electricity, depending on components that use direct current. Odeh et al. (2006) found that at low insolation subsystem efficiency increased with increasing insolation and with decreasing pumping head up to certain insolation level. This insolation level is known by the design insolation point at which pump reaches its maximum speed and capacity. At higher insolation, pumping head became the dominant parameter affecting subsystem efficiency. However, they found that in order to determine the optimum pumping head that required to determine average efficiencies for the concerned period. Ghoneim (2006) showed that the water pumping system consists of: the photovoltaic array and the pumping unit (motor and pump). Kulkarni et al. (2007) found that the $I_{s c}$ and $V_{o c}$ values were increased by increasing the amount of incident solar radiation. Consequently $\mathrm{I}_{\max }$ and $\mathrm{V}_{\max }$ were increased by increasing the incident solar radiation. Meah et al. (2008) showed that solar water pumping has several advantages over traditional systems. Solar systems are environment friendly, low maintenance, and have no fuel cost. Alternatively, PV systems do not create any emissions and use of Solar Photovoltaic Water Pumping (SPVWP) systems for remote water pumping could reduce both air and sound pollution. The SPVWP system has excellent performance in terms of productivity, reliability, and cost effectiveness. Dong (2009) found that decreasing panel tilt tended to increase the percent insolation of the front panel. This was expected because the altitude angle of the sun was high during the time of data collection. Furthermore, increasing cloud cover both of the percentage of direct irradiance and diffuse irradiance were increased. Mandal and Naskar (2012) observed that by increasing the discharge and pressure the efficiency increased. Benghanem et al. (2013) determined optimum photovoltaic (PV) array configuration, adequate to supply a DC Helical pump with optimum energy amount, under the outdoor conditions of 
Madinah site. Chandel et al. (2015) said that the first generation PV pumping systems used centrifugal pumps driven by DC/AC motors with hydraulic efficiencies varying from $25 \%$ to $35 \%$ whereas second generation PV pumping systems use positive displacement pumps, progressing cavity pumps or diaphragm pumps with high hydraulic efficiencies of even 70\%. Muhsen et al. (2017) reviewed the photovoltaic water pumping system (PVPS) performance and reported that, the average overall system's efficiency is about $3.4 \%$. Therefore, the main objective of this work was determination of critical irradiance (required radiation to start operating pump) and overall efficiency of PV panel and centrifugal pump system used to lift water from low well.

\section{MATERIAL AND METHODS}

\subsection{Experimental components and site}

The PV array or panel consists of a four modules constructed on sun tracking device allow horizontal and vertical moving with the direction of the sun. The PV array specifications were tabulated in Table 1. A pump (submersible - model 02) made in Italy, delivery volume of $5678 \mathrm{l} / \mathrm{h}$. High pumping capacity and reliability at a lower cost, delivery head of $6 \mathrm{~m}$, discharge outlet diameter of $28.6 \mathrm{~mm}, 12$ volts, 9 Amp, DC motor driving a centrifugal pump type connected to a PV array directly. Water well was found in the experimental site as source of water. The main three components, panel, pump and well represent a system to water pumping by solar energy. Schematic diagram of experiment system was illustrated in Figure 1.

Table 1. PV array specifications

\begin{tabular}{|l|l|l|l|}
\hline Module Type & ExSol 35W & Number of cells & 36 \\
\hline Size of module & $586 \times 410 \times 25 \mathrm{~mm}$ & Maximum power & $35 \mathrm{~W}$ \\
\hline Number of module & 4 & Total Maximum power & $140 \mathrm{~W}$ \\
\hline Open circuit voltage & $21.8 \mathrm{~V}$ & Short circuit current & $2.27 \mathrm{~A}$ \\
\hline Voltage at max power & $17.7 \mathrm{~V}$ & Current at max power & $1.98 \mathrm{~A}$ \\
\hline
\end{tabular}




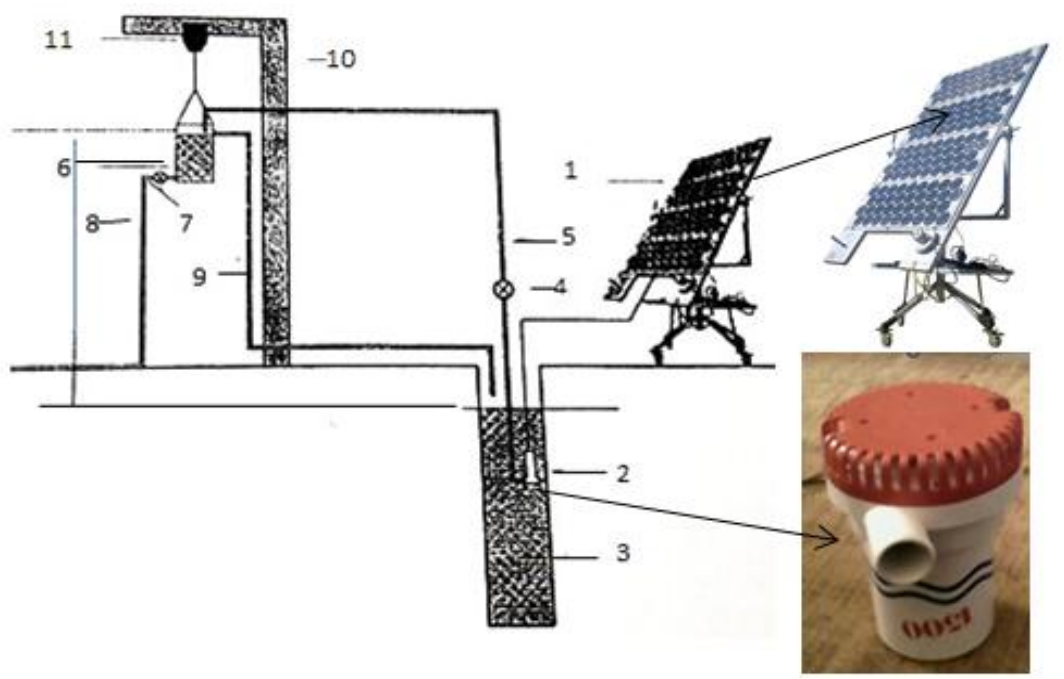

1-The photovoltaic modules

2-Centrifugal pump

3-The well

4-Valve

5- Pipe to transmit the water from well to tank

6- Tank
7-Valve

8-Pipe to transmit the water from tank to ground 9-Pipe to transmit the water from tank to well 10-Carrier

11- Lifter

Figure 1. Schematic diagram of experimental system

Experiments were performed at Agricultural Engineering Department, Faculty of Agriculture, Kaferelsheikh University during summer and winter of 2014 and 2015, respectively.

\subsection{Measuring Instruments}

The experimental test stand was comprised of Pyranometer, two multimeter, compass, anglevel meter, water balance, digital thermometer, metal meter, and stop watch.

\subsection{Experimental factors and parameters of the study}

The experimental studies were confined to determine the effect of daytime, solar irradiance and water heads of 2, 3 and $4 \mathrm{~m}$ (water head is static and delivery head between the level water in well and water tank) at panel tilt angle of $20^{\circ}$ in summer and $50^{\circ}$ in winter and panel orientation from east to west under actual outdoor conditions for average of many clear sunny days. The present work had many parameters as follows: Pump discharge ( $\ell / \mathrm{min})$, daily number of operating hours of the pump, useful energy for water pumping, hydraulic power (W), subsystem efficiency $(\%)$ and overall efficiency $(\%)$. 


\section{a) Input and output power to the system}

The insolation to the PV array gives the input power to the system and output power by using equations (from Lal et al. 2013) as follows:

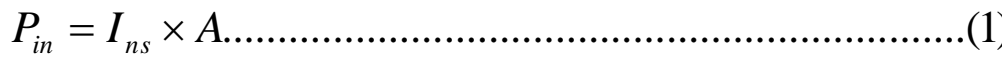

$$
\begin{aligned}
& P_{\text {out }}=V_{o c} \times I
\end{aligned}
$$

Where:

$\mathrm{P}_{\text {in }}$ : input power $(\mathrm{W}) ; \mathrm{P}_{\text {out }}$ : output power $(\mathrm{W}) ; \mathrm{I}_{\mathrm{ns}}$ : insolation $\left(\mathrm{W} / \mathrm{m}^{2}\right)$; A: solar module area $\left(\mathrm{m}^{2}\right) ; \mathrm{V}_{\mathrm{oc}}$ : open circuit voltage $(\mathrm{V}) ; \mathrm{I}_{\mathrm{sc}}$ : short circuit current (A).

b) The hydraulic power output

The hydraulic power output of the pump is the power required to lift a volume of water through a given head and calculated by using the following equation (from Lal et al. 2013):

$$
P_{h}=\rho \times g \times Q \times H .
$$

Where: $\mathrm{P}_{\mathrm{h}}$ : hydraulic power output of the pump (W); $\rho$ : water density $\left(\mathrm{kg} / \mathrm{m}^{3}\right) ; \mathrm{g}$ : acceleration of gravity $\left(\mathrm{m} / \mathrm{s}^{2}\right)$; Q: pump discharge $\left(\mathrm{m}^{3} / \mathrm{s}\right), \mathrm{H}$ : total pumping head $(\mathrm{m})$.

\section{c) PV panel efficiency}

PV panel efficiency ( $\left.\eta_{\text {panel }}\right)$ is the ratio between output power to input power. It uses to measure of how efficient the PV panel is in converting sunlight to electricity. The efficiency was calculated by the following equation (from Lal et al. 2013):

$$
\eta_{\text {panel }}=\frac{P_{\text {out }}}{P_{\text {in }}} \times F F=\frac{V_{O C} \times I_{S C} \times F F}{I_{n s} \times A} \times 100 .
$$

Where: FF: fill factor which equals about 0.67 for Si.

\section{d) Subsystem efficiency}

Subsystem efficiency $\left(n_{s}\right)$ is the efficiency of the entire system components (from Lal et al. 2013): 


$$
\eta_{s}=\frac{P_{h}}{P_{\text {output }}} \times 100
$$

\section{e) Overall efficiency}

Overall efficiency ( $\left.\eta_{\text {overall }}\right)$ indicates how efficiently the overall system converts insolation into water delivery at a given head (from Lal et al. 2013).

$$
\eta_{\text {overalll }}=\frac{P_{h}}{P_{\text {in }}} \times 100=\eta_{\text {panel }} \times \eta_{s}
$$

\section{RESULTS AND DISCUSSION}

\subsection{Effect of solar radiation on pump discharge}

Figures 2 and $\mathbf{3}$ show the effect of solar radiation on pump discharge at different water heads in both summer and winter, respectively. In summer at constant radiation $700 \mathrm{~W} / \mathrm{m}^{2}$ the pump discharge values were $39.98,37.00$ and $32.13 \mathrm{l} / \mathrm{min}$ at 2,3 and $4 \mathrm{~m}$ water head, respectively. These values were $32.06,34.74$ and $37.00 \mathrm{l} / \mathrm{min}$ at 500, 600 and $700 \mathrm{~W} / \mathrm{m}^{2}$ solar radiation respectively, when the water head was $3 \mathrm{~m}$. Pump discharge versus irradiance at different heads has the same trend in winter, differed in magnitude according to the electric power generated from the PV. At constant radiation $700 \mathrm{~W} / \mathrm{m}^{2}$ the pump discharge values were $43.50,41.00$ and $40.46 \ell / \mathrm{min}$ at 2 to 3 to $4 \mathrm{~m}$ water head, respectively. These values were 34.56 to 39.35 to $41.00 \ell / \mathrm{min}$ at 500,600 and $700 \mathrm{~W} / \mathrm{m}^{2}$ solar radiation, respectively when the water head was $3 \mathrm{~m}$. The minimum values of irradiance, necessary to start the water pump operation (the critical irradiance levels). It is clear that the critical irradiance $\left(\mathrm{I}_{\mathrm{C}}\right)$ tended to increase the water head. In summer the critical irradiance at heads of $2 \mathrm{~m}, 3 \mathrm{~m}$ and $4 \mathrm{~m}$ were $257.14,328.57$ and $628.57 \mathrm{~W} / \mathrm{m}^{2}$. In winter critical irradiance has the same trend, differed in magnitude due to panel temperature. $\mathrm{I}_{\mathrm{C}}$ values at the water head 2, 3 and $4 \mathrm{~m}$ were 242.86 to 285.72 to $571.43 \mathrm{~W} / \mathrm{m}^{2}$, respectively. 


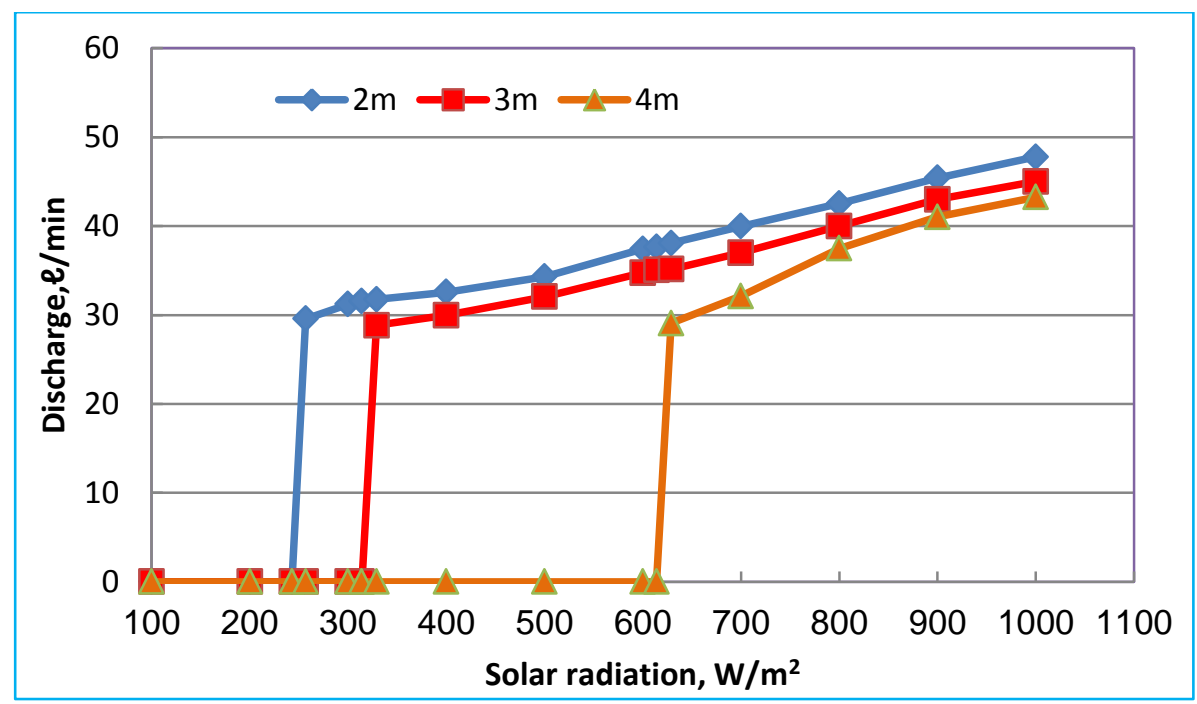

Figure 2. Effect of solar radiation on pump discharge at different water heads in summer

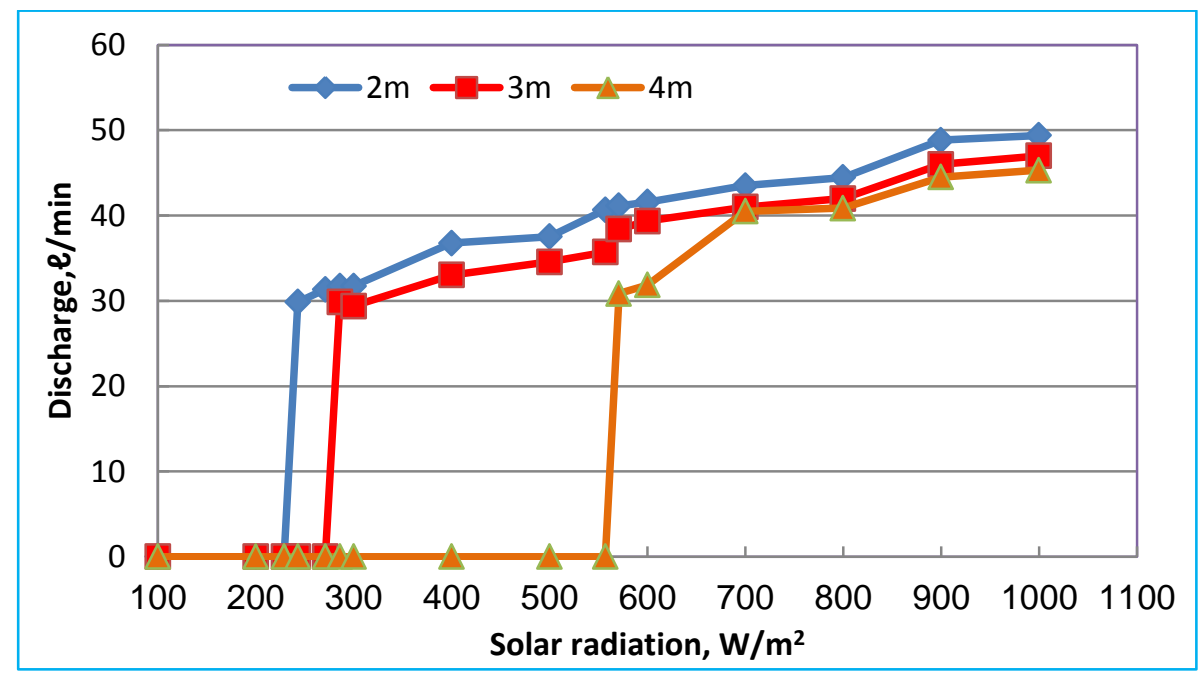

Figure 3. Effect of solar radiation on pump discharge at different water heads in winter

\subsection{Effect of daytime on pump discharge and operating time intervals}

From Figures $\mathbf{4}$ and 5, the pump discharge increased along daytime from sunrise till noon when it reached its maximum value then it decreased with sunset. The maximum values of pump discharge were 48.82, 47.92, 
$44.91 \ell / \mathrm{min}$ at $2,3,4 \mathrm{~m}$ water head, respectively when the daytime was $1 \mathrm{PM}$ and summer.

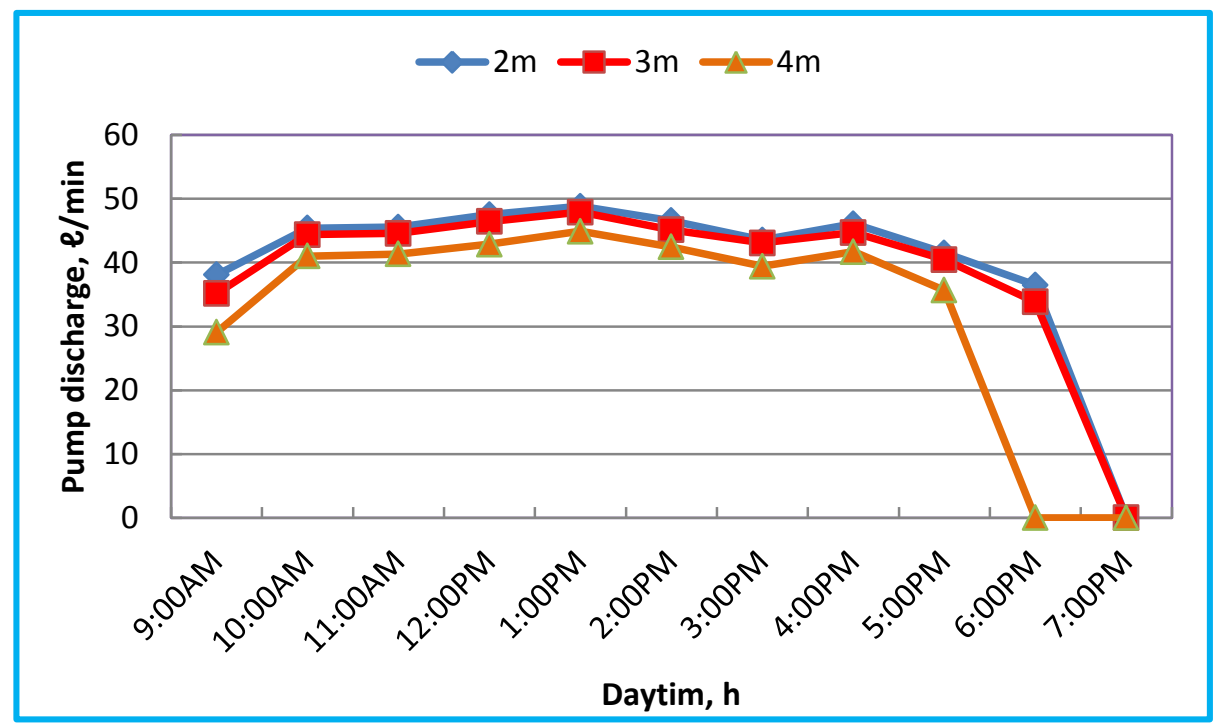

Figure 4. Discharge versus daytime at different heads in summer

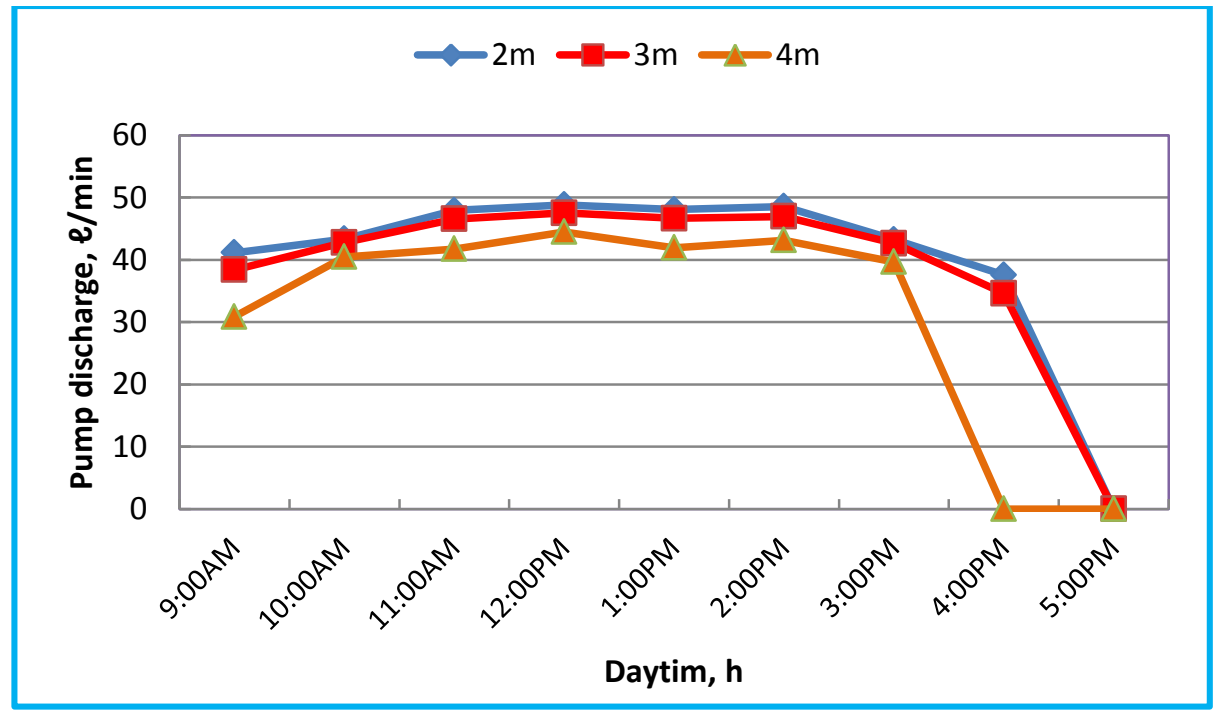

Figure 5. Pump discharge versus daytime at different heads in winter 
The maximum values of pump discharge were 48.83, 47.54, 44.49l/min at 2, 3 and $4 \mathrm{~m}$ water head, respectively when the daytime was $12 \mathrm{PM}$ and winter. Also, water head increased tended to increase the amount of collected solar energy above the critical irradiance and the useful energy for pump discharge, i.e. larger amount of useful energy produced from the panel convert to discharge although it pump less water. That because, when the water head increased, the critical irradiance increased and the pump operated a fewer hours consequently, pump discharge was less. The time interval of pump operating decreased with the increasing of water head. Also it was longer in summer than in winter. The maximum time interval was about of $10,9.5$ and $9 \mathrm{~h}$ in summer and 8.0, 7.5 and $7.0 \mathrm{~h}$ in winter at 2,3 and $4 \mathrm{~m}$ water head, respectively.

\subsection{Effect of solar radiation on output electric power, pump discharge and hydraulic power}

Effect of solar radiation intensity $\left(\mathrm{W} / \mathrm{m}^{2}\right)$ on output electric power $(\mathrm{W})$, hydraulic power $(\mathrm{W})$ and pump discharge $(\ell / \mathrm{min})$ were shown in Figures 6 and 7. Increasing solar radiation and output electric power tended to increase both of water head and pump discharge, so the hydraulic power will be increase. Increasing volume of water and the head which required to be lifted required more power to lift this volume through a given head. That power is known as hydraulic power. When solar radiation was increased from 700 to $1000 \mathrm{~W} / \mathrm{m}^{2}$, output electric power increased from 57.25 to $78.26 \mathrm{~W}$, pump discharge increased from 39.9 to $47.7 \ell / \mathrm{min}$ and hydraulic power increased from $13.07 \mathrm{~W}$ to $15.6 \mathrm{~W}$ at $2 \mathrm{~m}$ water head. The pump discharge was increased from 38.8 , to $46.7 \ell / \mathrm{min}$ and hydraulic power increased from 19.05 to $22.9 \mathrm{~W}$ at $3 \mathrm{~m}$ water head. At $4 \mathrm{~m}$ water head increasing pump discharge from 32.1 to $43.2 \mathrm{l} / \mathrm{min}$ tended to increase the hydraulic power from $21.01 \mathrm{~W}$ to $28.20 \mathrm{~W}$ in summer. Similarly, when solar radiation increased from 700 to $1000 \mathrm{~W} / \mathrm{m}^{2}$, output electric power increased from 65.93 to $83.98 \mathrm{~W}$, pump discharge increased from 43.5 to $49.3 \mathrm{l} / \mathrm{min}$ and the hydraulic power increased from 14.2 to $16.1 \mathrm{~W}$ at $2 \mathrm{~m}$ water head. The Discharge increased from 42.8 to 


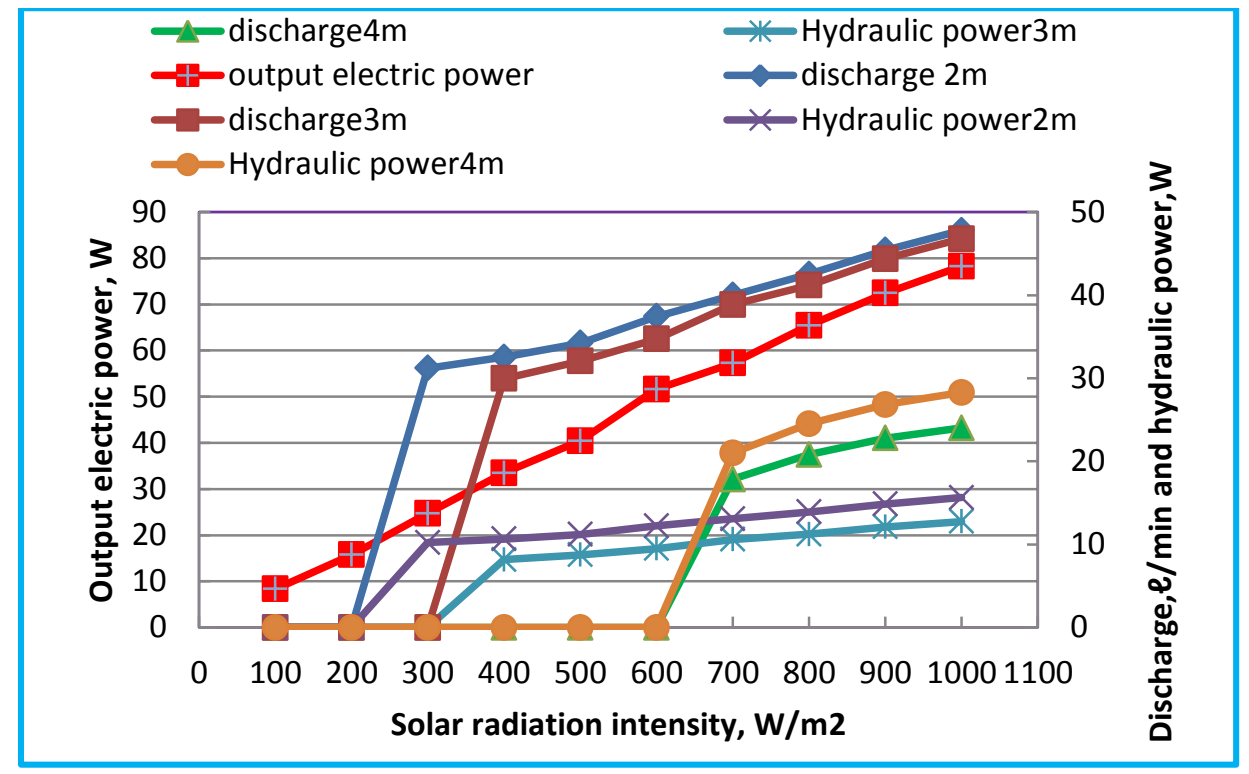

Figure 6. Effect of solar radiation on output electric power, discharge and hydraulic power and in summer

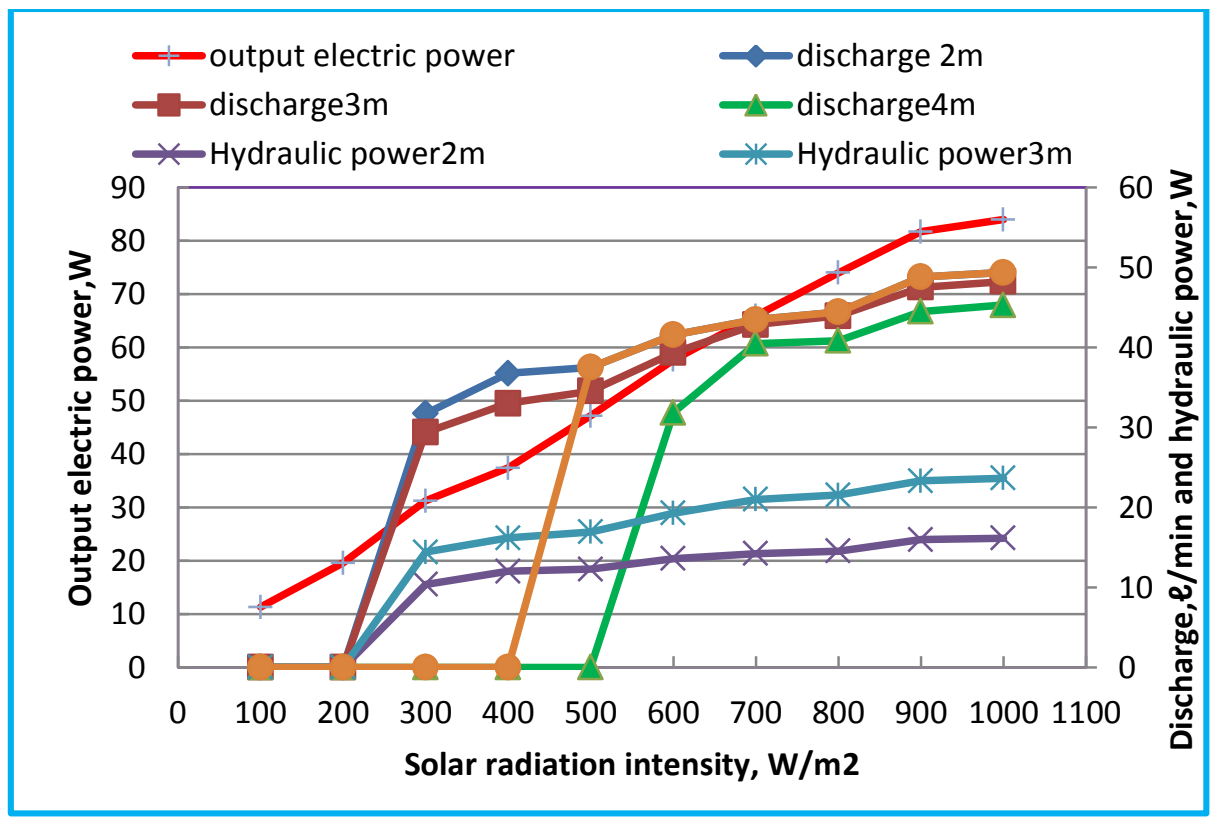

Figure 7. Effect of solar radiation on output electric power, discharge and hydraulic power and in winter 
$48.2 \ell / \mathrm{min}$ and the hydraulic power increased from 21.02 to $23.6 \mathrm{~W}$ at $3 \mathrm{~m}$ water head. At $4 \mathrm{~m}$ water head increasing pump discharge from 40.4 to $45.3 \mathrm{l} / \mathrm{min}$ tended to increase the hydraulic power from 26.40 to $29.60 \mathrm{~W}$ in winter.

\subsection{Effect of daytime and solar radiation on subsystem and overall efficiency.}

The subsystem efficiency and the overall efficiency have the same trend. They both increase from $0 \%$ for no discharge to reach the peak at the critical irradiance then they reduce with the increase in solar radiation during the daytime. They also decrease with the increase in head from 2 to $4 \mathrm{~m}$ as shown in Figures $8(\mathbf{a}, \mathbf{b}), 9(\mathbf{a}, \mathbf{b}), 10(\mathbf{a}, \mathbf{b})$ and $11(\mathbf{a}, \mathbf{b})$. The average percent of subsystem efficiency (all percent divided by number of operating intervals) was $11.73,16.91$ and $20.09 \%$ at 2,3 and $4 \mathrm{~m}$ water head, respectively in summer from 9AM to 7PM. Also, it was $12.78,18.44$ and $19.11 \%$ at 2,3 and $4 \mathrm{~m}$ water head, respectively in winter from 9AM to 5PM. The average percent of overall efficiency (all percent divided by number of operating intervals) was 1.91, 2.82 and $3.00 \%$ at 2,3 and $4 \mathrm{~m}$ head, respectively in summer from 9AM to 7PM. Also, it was $2.16,3.11$ and $3.19 \%$ at 2,3 and $4 \mathrm{~m}$ head, respectively in winter from 9AM to 5PM. The subsystem efficiency was increased from $0 \%$ to reach the peak of $30.72,35.85$ and $23.63 \%$ at the critical irradiance was $257.14,328.57$ and $628.57 \mathrm{~W} / \mathrm{m}^{2}$ then it reduced with the increasing of solar radiation to reach $13.38,19.65$ and $24.21 \%$ at 2, 3 and $4 \mathrm{~m}$ water head, respectively when solar radiation was $1000 \mathrm{~W} / \mathrm{m}^{2}$ in summer. The overall efficiency was increased from $0 \%$ to reach the peak $3.13,3.59$ and $2.52 \%$ at the critical irradiance was $257.14,328.57$ $628.57 \mathrm{~W} / \mathrm{m}^{2}$ then it reduced with the increasing of solar radiation to reach $1.30,1.91$ and $2.36 \%$ at 2, 3 and $4 \mathrm{~m}$ head, respectively when solar radiation was $1000 \mathrm{~W} / \mathrm{m}^{2}$ in summer. The subsystem efficiency was increased from $0 \%$ to reach the peak $25.94,32.45$ and $24.55 \%$ at the critical irradiance was $242.86,285.71$ and 571.43 then it reduced with the increasing of solar radiation to $12.88,18.88$ and $23.65 \%$ at 2,3 and 
$4 \mathrm{~m}$ water head, respectively when solar radiation was $1000 \mathrm{~W} / \mathrm{m}^{2}$ in winter. The overall efficiency increased from $0 \%$ to reach the peak 4.823 , 5.77 and $4.24 \%$ at the critical irradiance was 242.86, 285.71 and 571.43 $\mathrm{W} / \mathrm{m}^{2}$, then it reduced with the increasing of solar radiation to reach 1.938, 2.84 and $3.56 \%$ at 2,3 and $4 \mathrm{~m}$ water head, respectively when solar radiation was $1000 \mathrm{~W} / \mathrm{m}^{2}$ in winter. This reduction was found due to high panel temperature.
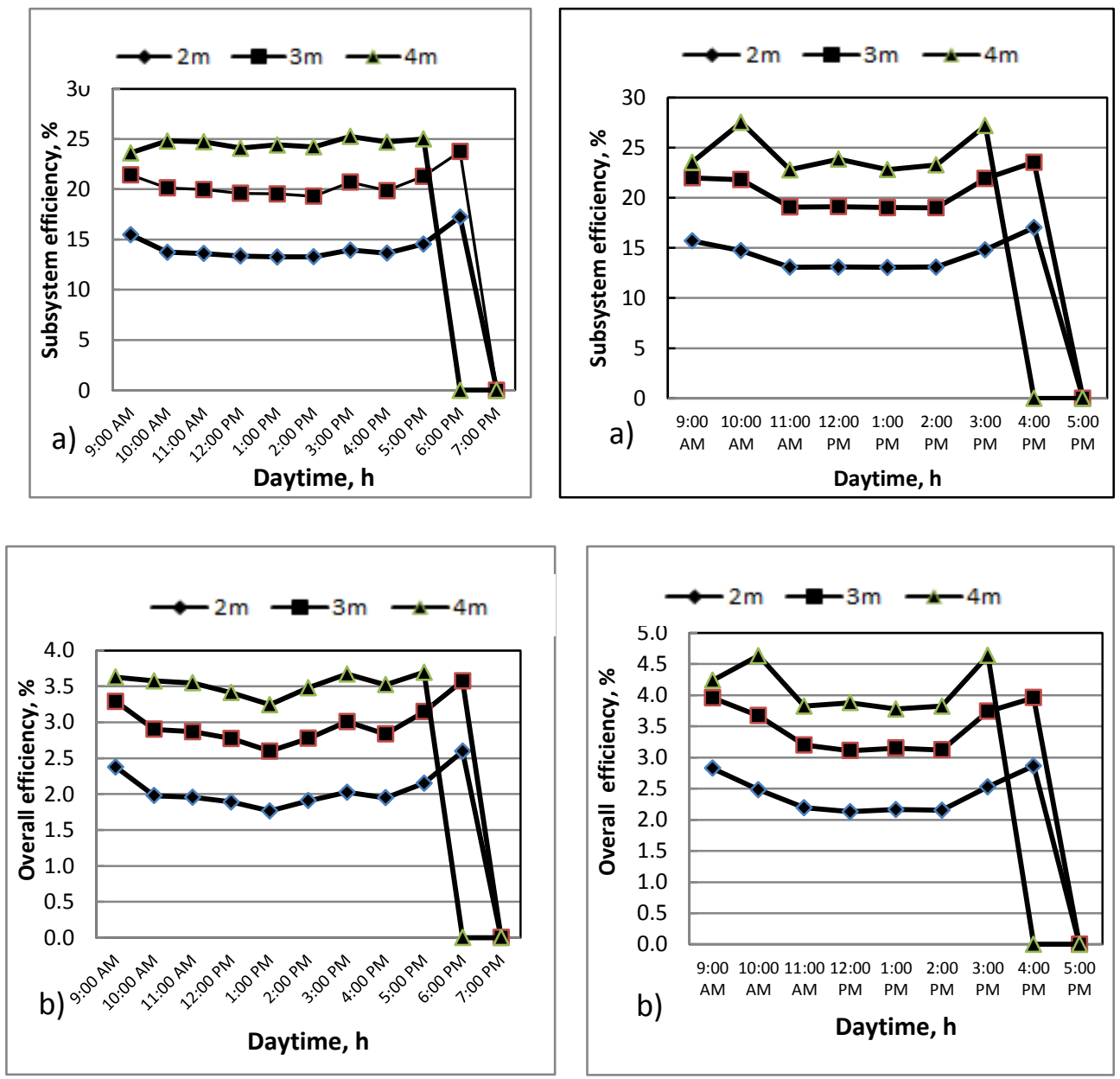

Figure 8. Subsystem and overall efficiency versus daytime in summer.

Figure 9. Subsystem and overall efficiency versus daytime in winter. 

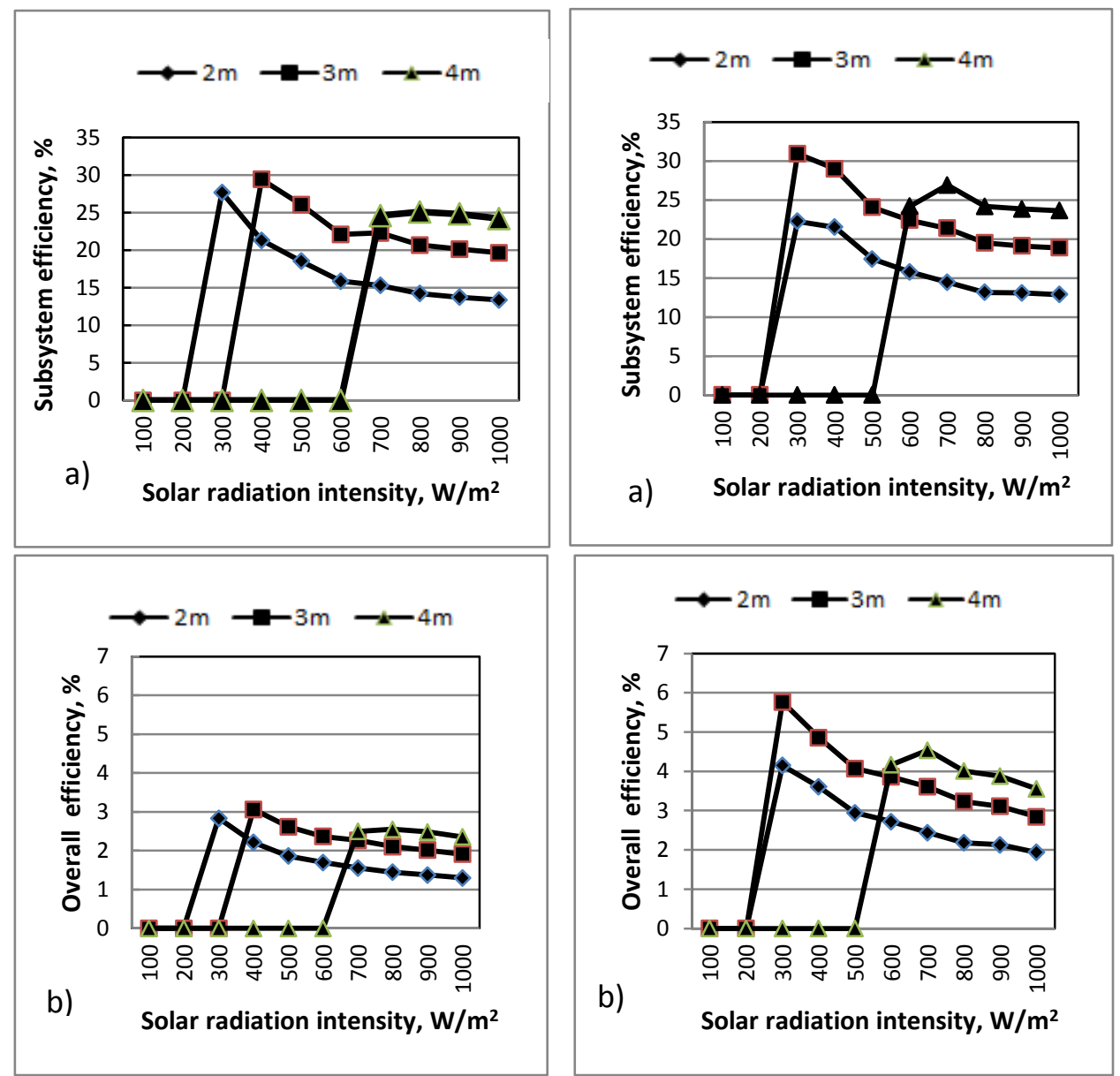

Figure 10. Subsystem and overall efficiency versus solar radiation in summer

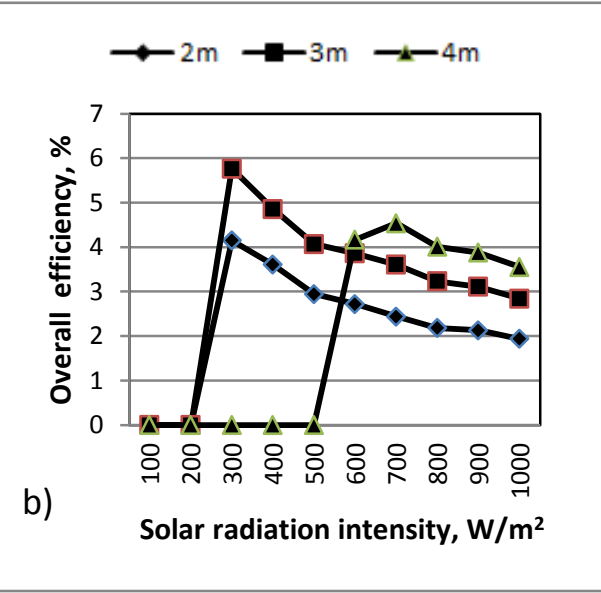

Figure 11. Subsystem and overall efficiency versus solar radiation in winter

\section{CONCLUSIONS}

It has been concluded that:

- The discharge increased along daytime from sunrise till noon when it reached its maximum value then it decreased with sunset.

- The hydraulic power directly affects by the head and discharge which affects with radiation and output electric power from the panel. When the water head and pump discharge increased, due to increased radiation and output electric power, the hydraulic power increased. 
- The subsystem efficiency and the overall efficiency have the same trend. They both increased from no discharge to reach the peak at the critical irradiance then they reduced with the increased in solar radiation during the daytime. They also decreased with increasing of water head from 2 to $4 \mathrm{~m}$ under experimental conditions.

\section{REFERANCES}

Awady, M. N.; M. F. A. Sallam and A. M. Hegazi (2002). Performance of solar powered drip irrigation system. Misr J. Ag. Eng. 19(2):297-312.

Badescu, V. (2003). Time dependent model of a complex PV water pumping system. Renewable Energy. 28: 543-560.

Benghanem, M.; K. O Daffallah; A. A. Joraid; S. N.Alamri and A. Jaber (2013). Performances of solar water pumping system using helical pump for a deep well: A case study for Madinah, Saudi Arabia. Energy Conversion and Management. 65: 50-56.

Chandel, S. S.; M. N. Naik and R. Chandel (2015). Review of solar photovoltaic water pumping system technology for irrigation and community drinking water supplies. Renewable and Sustainable Energy Reviews. 49: 1084-1099.

Dong, R. (2009). Optimizing Reflection and Orientation for Bifacial Photovoltaic Modules. Thesis, department mechanical engineering, Ohio State University.

El-Sayed, A. S.; S. M. Radwan; A. A. Hassanain and S. M. Mosalhi, (2005). Effect of orientation and tilt angle on stand-alone solar module performance for simple integrated water pumping system. Misr Journal of agricultural engineering, 22(3): 943-962.

Ghoneim, A. A. (2006). Design optimization of photovoltaic powered water pumping systems. Energy Conversion and Management 47:1449-1463. 
Hahn, A.; R. Schmidt; Ar. Torres and Am. Torres (2000). Resourceconserving irrigation with photovoltaic pumping systems. Proceedings of $16^{\text {th }}$ European Photovoltaic Solar Energy Conference and Exhibition, 1-5 May 2000, Glasgow, Scotland.

Hamidat, A.; B. Benyoucef and T. Hartani (2003). Small-scale irrigation with photovoltaic water pumping system in Sahara regions. 28: 1081-1096

Hamidat, A. (2000). Simulation des performances d'irrigation du pompage PV dans un milieu Saharien. Proceedings of the Colloque sur l'Héliothermique l'Environnement et la Maîtrise des Systèmes Solaires, ISSN 1112-2880, 13-15 Mai 2000, Algeria.

Kasem, A. S., (2004). Agricultural application of solar energy and wind energy. I.S.B.N. 977-5030-60-9.

Kulkarni, S.; S. Tonapi; P. Larochelle; K. Mitra (2007). Effect of tracking flat reflector using novel auxiliary drive mechanism on the performance of stationary photovoltaic module. ASME International Mechanical Engineering Congress and Exposition. November 11.

Lal, S.; P. Kumar and R. Rajora (2013). Performance analysis of photovoltaic based submersible water pump. International Journal of Engineering and Technology. 5(2): 552-560.

Mandal, R., and Naskar, R. (2012). A Study of Solar Photovoltaic Application in Irrigation System and Its Performance Analysis in Laboratory Scale.International Journal of Advanced Alternative Energy, Environment and Ecology. 1(1): 1-14.

Meah, K.; S. Fletcher and S. Ula (2008). Solar photovoltaic water pumping for remote locations. Renewable and Sustainable Energy Reviews. 12: 472-487.

Muhsen, D. H.; T. Khatib and F. Nagi (2017). A review of photovoltaic water pumping system designing methods, control strategies and field performance. Renewable and Sustainable Energy Reviews. 68: 70-86. 
Odeh, I.; Y. G. Yohanis and B. Norton (2006). Influence of pumping head, insolation and PV array size on PV water pumping system performance. Solar Energy. 80: 51-64.

Pande, P. C.; A. K. Singh; S. Ansari; S. K. Vyas and B. K. Dave (2003). Design development and testing of a solar PV pump based drip system for orchards. Renewable Energy 28 :385-396.

Vilela, O. C. and N. Fraidenraich (2001). A Methodology for the Design of Photovoltaic Water Supply Systems. Progress in photovoltaic: research and applications 9:349-361(DOI: 10.1002/pip. 386).

Vilela, O. C.; N. Fraidenraich and C. Tiba (2003). Photovoltaic pumping systems driven by tracking collectors. Experiments and simulation. Solar Energy. 74:45-52.

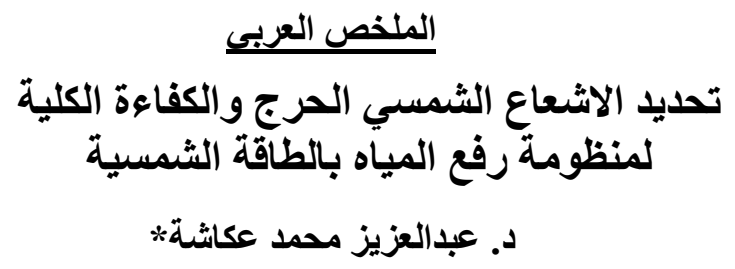

نواجه مصر مشكلة غزو المناطق الصحراوية في كيفية توفير المياه للزراعة والافتقار للطاقة

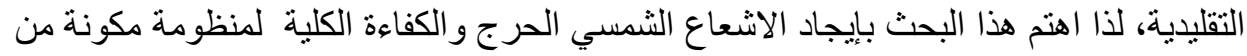

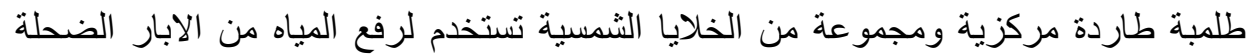

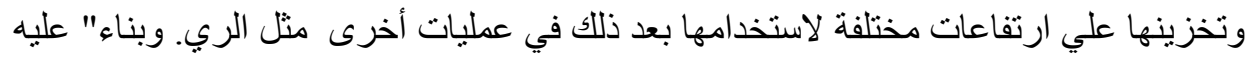

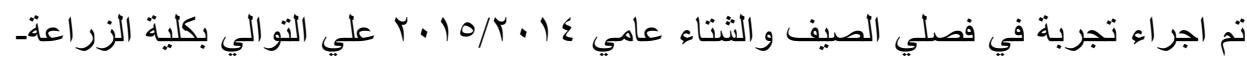

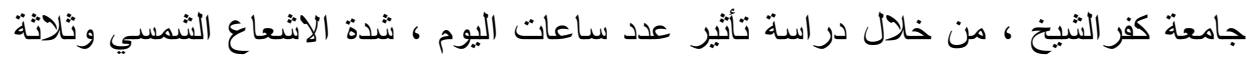

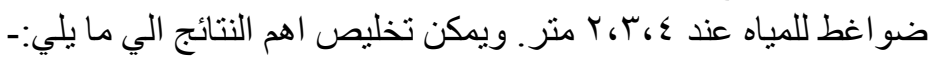

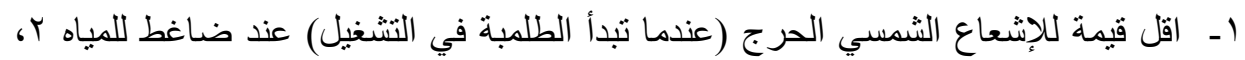

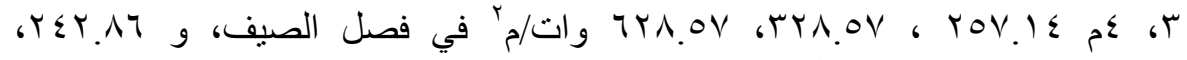
( T)

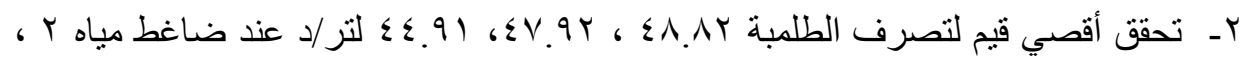

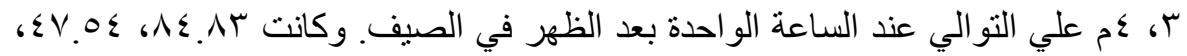

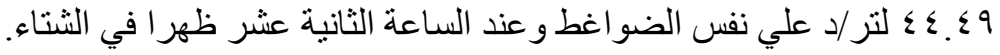

*مدرس الهندسة الزراعية ـ قسم الهندة الزراعية ـ كلية الزراعة ـ جامعة كفر الثيخ 


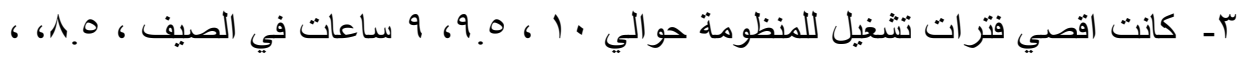

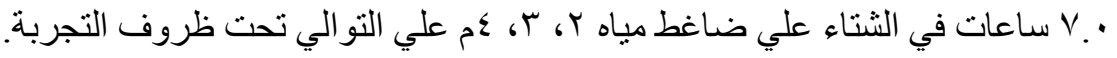

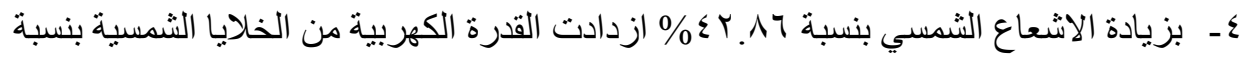

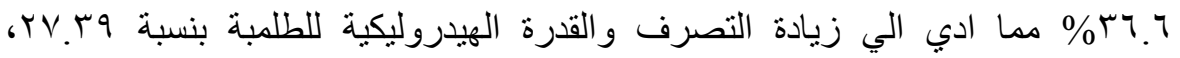

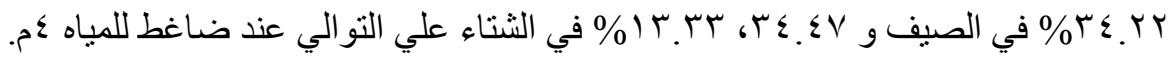

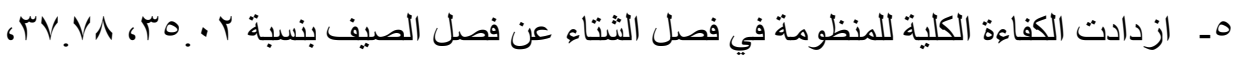

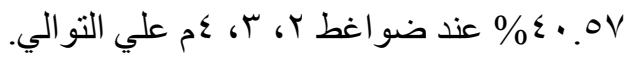

